$1-2012$

\title{
Significant Race Differences in Factors Related to the Detention Recidivism of Youthful Offenders
}

Christopher A. Mallett

Cleveland State University, c.a.mallett@csuohio.edu

Miyuki Fukushima

Cleveland State University, m.fukushima@csuohio.edu

Patricia A. Stoddard Dare

Cleveland State University, p.stoddarddare@csuohio.edu

Linda M. Quinn

Cleveland State University, I.quinn@csuohio.edu

Follow this and additional works at: https://engagedscholarship.csuohio.edu/clsowo_facpub

Part of the Psychiatric and Mental Health Commons, Race and Ethnicity Commons, and the Social Control, Law, Crime, and Deviance Commons

How does access to this work benefit you? Let us know!

Publisher's Statement

(c) 2012 Taylor \& Francis

\section{Recommended Citation}

Mallett, Christopher A.; Fukushima, Miyuki; Stoddard Dare, Patricia A.; and Quinn, Linda M., "Significant Race Differences in Factors Related to the Detention Recidivism of Youthful Offenders" (2012). Social Work Faculty Publications. 6.

https://engagedscholarship.csuohio.edu/clsowo_facpub/6

This Article is brought to you for free and open access by the School of Social Work at EngagedScholarship@CSU. It has been accepted for inclusion in Social Work Faculty Publications by an authorized administrator of EngagedScholarship@CSU. For more information, please contact library.es@csuohio.edu. 


\title{
Significant Race Differences in Factors Related to the Detention Recidivism of Youthful Offenders
}

\author{
CHRISTOPHER A. MALLETT, MIYUKI FUKUSHIMA, \\ PATRICIA STODDARD-DARE, and LINDA M. QUINN \\ Cleveland State University, Cleveland, Ohio, USA
}

A significant number of youthful offenders in the United States are held in juvenile court detention centers. Of broad concern is the disproportionate impact these placements have on minority youth, with African American and Hispanic youth much more frequently detained in these facilities compared to Caucasian youth. This U.S. study of a 2-county youthful offender population in the Midwest (1 urban, 1 rural) investigated racial differences in both extralegal (demographic, educational, mental health, and history of abuse or neglect) and court-related legal variables that predict detention placement upon recidivism - in other words, a second detention placement. Findings from logistic regression analysis indicated that only a few legal factors (violation of a court order, number of court offenses) predicted for both minority and Caucasian youth, but numerous racially disparate extralegal factors also predicted detention placement upon recidivism. Specifically, unique predictors for minority youth included a history of abuse or neglect, suicide attempt, and mental health diagnoses. These findings support the racially differential treatment explanation for detention placements as well as offer interventive opportunities for juvenile court personnel to reduce disproportionate minority confinement among youthful offenders.

KEYTERMS Recidivism, detention, delinquency, youth, race, legal factors, extralegal factors

Address correspondence to Christopher A. Mallett, PhD, Esq., LISW, Cleveland State University, 2121 Euclid Avenue, \#CB324, Cleveland, OH 44115. E-mail: c.a.mallett@csuohio.edu 


\section{INTRODUCTION}

Most youthful offenders in the United States are not held for any length of time within a juvenile court's detention center. Although this is considered reasonable juvenile justice system policy, there is significant and growing concern for those youth who do end up in placement. In fact, of the 1.7 million youth who come under the control and supervision of the juvenile courts annually, 21\% are placed in a detention center (Knoll \& Sickmund, 2010; Sickmund, 2008). In addition, this detainment of youth is a widely available dispositional option to the courts in the United States. In 32 of the 50 states detention placement can be utilized as a juvenile court disposition (court decision) either at the time of arrest or pending court action, and in 40 of the 50 states detention is used as a sanction for probation (supervision) violations (National Center for Juvenile Justice, 2006; Sedlak \& Bruce, 2010).

The concern is that these youthful offender detention placements are harmful for a number of reasons. First, many times the detention experience itself is a causal factor in subsequent reoffending (Holman \& Ziedenberg, 2006; Mallett \& Julian, 2008). This increased recidivism outcome runs counter to the U.S. juvenile justice system's policy goals of community safety, youth accountability, and youth rehabilitation (U.S. Department of Justice, 2010). And second, though it is not fully understood, race is a significant predictor of detention placement outcomes: African American youthful offenders are 6 times more likely and Hispanic youthful offenders 3 times more likely than Caucasian youthful offenders to be detained, even when many of the important legal factors are controlled (Bishop, 2006; Kempf-Leonard, 2007; Mauer \& King, 2007; National Council on Crime and Delinquency, 2007; Piquero, 2008; Puzzanchera, Adams, \& Snyder, 2008). For these reasons, reducing detention utilization in the United States and the racial disparity of these placements are important social policy and juvenile justice system policy goals (U.S. Department of Justice, 2010). Thus, the present study investigates the racial differences in factors that are associated with detention placement upon recidivism for youthful offenders.

\section{BACKGROUND}

\section{Differential Treatment Theory and Youthful Offenders' Disabilities}

There are broad and differing explanations for the racial disparities found within juvenile detention facilities, a phenomenon called disproportionate minority confinement (Piquero, 2008). Four main theories attempt to conceptualize and explicate this overrepresentation of minority youth with varying degrees of empirical support: differential involvement (different rates of youth offending leading to the disparities), structural-processual (the impact of multiple decision-making points in the juvenile justice process with racial 
bias occurring at multiple points), macro-contextual (community and court characteristics leading to the racial differences in social control), and differential treatment (explained below; Bishop \& Frazier, 1992; Bridges, Crutchfield, \& Simpson, 1987; Engen, Steen, \& Bridges, 2002; Hawkins, 1987; Hill, Harris, \& Miller, 1985; Johnson \& Secret, 1990; Sampson \& Laub, 1993).

Of interest, and theoretical importance, here is differential treatment theory. This theory posits that racial discrimination occurs indirectly through other social characteristics-including family structure, socioeconomic status, youth personality traits, school status and difficulties, and other related characteristics (Cohen \& Kluegel, 1978; Farmer et al., 2004; Pope \& Feyerherm, 1990; Rodriquez, 2010). It is thought that race is related to juvenile court outcomes through these characteristics because race is significantly related to these important characteristics that in turn affect juvenile court outcomes (Bortner, Sunderland, \& Winn, 1985; Horwitz \& Wasserman, 1980; Meade, 1973). For example, in one empirical review of differential treatment theory with youthful offenders, negative youth characteristics (such as personality and cooperativeness) were attributed to African American youth, whereas negative peer, family, and school characteristics were attributed to Caucasian youth (Bridges \& Steen, 1998).

More recently there has been recognition within the juvenile courts of the significant impact various types of disabilities (e.g., school-related disabilities, mental health) may have on disproportionate minority confinement (Grisso, 2008). These disabilities are widely prevalent for youthful offenders in detention facilities, with 6 in 10 youth diagnosed with a mental health disorder (Grisso, 2008; Teplin et al., 2006), 4 in 10 having a significant substance abuse problem (Chassin, 2008; Sedlak \& McPherson, 2010), 3 in 10 identified with a special education disability (Krezmien, Mulcahy, \& Leone, 2008; Mears \& Aron, 2003), and at least 3 in 10 having been a victim of abuse or neglect (Center for Juvenile Justice Reform, 2010; Sedlak \& McPherson, 2010; Tuell, 2002). These disorder and disability rates are many times greater than the rates found in the general youth population (Mallett, 2009). Upward of half of these youthful offenders experience more than one of these disabilities concurrently (Garland et al., 2001; Scott, Snowden, \& Libby, 2002), complicating the investigations into their effects on disproportionate minority confinement (Mallett \& Stoddard-Dare, 2010). Furthermore, because of the multitude of individual, family, and community risk factors experienced by youthful offenders, predicting delinquency outcomes, particularly recidivism, as well as court disposition outcomes, is difficult (Ford, Chapman, Hawke, \& Albert, 2007; Gavazzi, Yarcheck, \& Lim, 2005; Green, Gesten, Greenwald, \& Salcedo, 2008; Gutman, Sameroff, \& Cole, 2003).

Juvenile courts in the United States typically utilize as the disposition (sentence) monitoring of youth both in the community and in detention center placements, including treatment referrals for supervised offenders in both settings. Some researchers have found that a referral for treatment 
service was one of the most common juvenile court dispositions, with 50\% of supervised youth being referred for treatment (Breda, 2003). The need for treatment referrals does not seem to differ by youths' race (Martin \& Grubb, 1990) in both short-term detention facilities (Rogers, Powell, \& Strock, 1998) and long-term detention facilities (Glisson, 1996). However, empirical studies have found that minority youth are more likely to be detained, and detained youth are more likely to receive additional harsh sanctions and less likely to receive treatment referrals than youth who are not detained (Leiber \& Fox, 2005; Wu, 1997). In other words, empirical studies have found that minority youth are more likely to be detained but are less likely to receive treatment referrals than Caucasian youth. If detention and lack of treatment significantly affect the likelihood of future reoffending, then the racially disparate juvenile court disposition not only continues the problem of disproportionate minority confinement but in fact exacerbates it.

\section{Justification for the Study}

It is important to investigate the impact of various extralegal youth characteristics (including race), youth and family risk factors, and youth disabilities on juvenile court outcomes. Because of the harmful impact of detention on youth and potentially racially biased utilization of such disposition, it is beneficial to know which of these characteristics are predictive of detention placement upon recidivism. Investigating whether there are differences in these detention placement predictions by race may help explicate the disproportionate minority confinement conundrum. In particular, measuring recidivism as a return placement of the youthful offender in detention, as this research study does, may help explicate differential treatment that occurred within these juvenile courts. This study specifically examines which extralegal characteristics (including demographic, educational, maltreatment, and mental health differences) and legal characteristics relate to differences in detention placement upon recidivism for Caucasian and minority youthful offenders.

\section{METHODS}

\section{Sampling}

This study utilized a sampling frame of all probation-supervised youth over a distinct period of time in two counties in one state of the U.S. Midwest region. An appropriate sample size was calculated using an a priori analysis. The first county (urban) had an annual population size of 2,300 probationsupervised youthful offenders, and the second county (rural) had an annual population size of 300 probation-supervised youthful offenders. From these 
it was determined that a sample size of 343 from the first county (over 3 years, 2006-2008) and a sample size of 90 from the second county (over 1 year, 2008) would provide the appropriate 5\% margin of error and 95\% confidence interval, assuming a population proportion of 50\% (Royse, Thyer, Padgett, \& Logan, 2006). A simple random sample was drawn from each year of the counties' probation-supervised youthful offender population. A total of 433 youth were included in this study sample: urban county $2006=100$; urban county $2007=137$; urban county $2008=105$; rural county $2008=91$.

\section{Data Collection}

Data were collected from existing de-identified files provided by each county's juvenile court. Each file contained official records associated with each youth in the study sample-specifically, juvenile court histories, probation supervision case files, and mental health assessments. Data from the case records were coded and entered into a statistical software package. Each case entered was evaluated for proper coding and correct data entry, with high intercoder reliability (.96).

\section{Measurement}

Variables that were theoretically and empirically relevant were measured for this study, including demographic, educational, child welfare, mental health, and juvenile justice variables.

\section{INDEPENDENT VARIABLES}

Demographic variables included race (Caucasian $=1$, minority $=0$ ), age (in years), gender (male $=1$ ), and county of residence (rural $=1$, urban $=$ 0 ). Three education disability variables (identified by school psychologists) were measured: severely behaviorally handicapped, developmentally handicapped, and severely emotionally disturbed. One child welfare-related variable was measured as child welfare system involvement because of substantiated abuse or neglect (yes $=1, \mathrm{n}=0$ ). Several mental health-related variables were included that were based on the diagnosis made by a licensed provider using Diagnostic and Statistical Manual of Mental Disorders, Fourth Edition (DSM-IV; American Psychiatric Association, 2000) criteria prior to the first juvenile court ordered supervision (yes $=1$ indicates a diagnosis). Mental health-related variables that were measured included attention-deficit/hyperactivity disorder (ADHD), conduct disorder, oppositional defiant disorder, bipolar disorder, depression, adjustment disorder, posttraumatic stress disorder, and anxiety disorder. In addition, substance 
use disorders were also measured: Youth were counted as substance dependent (coded yes $=1$ ) if they had a past or present diagnosis by a licensed provider using $D S M-I V$ criteria for dependence to any drug. Prior suicide attempt, another mental health-related variable, was measured using case record notation of a report of a prior suicide attempt by the youth, family, or licensed provider (yes $=1$ indicates a prior suicide attempt).

Several court-related, legal variables were also measured. These included the total number of times the youth was adjudicated delinquent (in number of times); the youth's age at his or her first delinquency adjudication (in years); the youth's total number of court offenses, which includes multiple offenses over time (in number of court offenses); the youth's prior conviction of a property crime, personal crime, drug-related crime, status offense, violation of a court order, misdemeanor, or felony (all coded yes $=$ 1 for a prior conviction). A small number of missing variables were imputed with either the mean (for continuous variables) or the mode (for categorical variables) except for juvenile court-related variables, for which missing cases (only one to two per variable) were eliminated from the analysis (see Table 1).

\section{DEPENDENT VARIABLE}

One dependent variable, recidivism, was measured (coded 1) if the youth were held in the detention center, were released from custody, and then were subsequently placed back in the detention center (in other words, if youth received detention placement upon recidivism). There were no missing cases for the dependent variable.

\section{DATA ANALYSIS}

Independent variables that were candidates for inclusion in the final explanatory models were chosen based on one of two criteria: the variable has been theoretically linked to the dependent variable or the variable was significantly related $(p<.10)$ to race in the univariate logistic regression (see Table 2). The first stage of modeling considered all candidate variables for inclusion in stepwise regression procedures. A first model used interaction terms with race to predict recidivism; however, the model did not perform well in validation samples. Then separate models were developed, one for Caucasian youth and one for minority youth. Both models included only variables that either were theoretically relevant or were significantly related to the dependent variable at the univariate level. The second stage of modeling included validation of the models. These models were checked for stability using repeated $80 \%$ validation samples from the data. Both models passed 
TABLE 1 Descriptive Statistics $(n=433)$

\begin{tabular}{|c|c|c|}
\hline Variable & Yes & No \\
\hline \multicolumn{3}{|l|}{ Predictor } \\
\hline Recidivated to placement & $71(16.4 \%)$ & $362(83.6 \%)$ \\
\hline \multicolumn{3}{|l|}{ Control } \\
\hline Age & \multicolumn{2}{|c|}{$M=15.2(S D=1.6)$} \\
\hline \multirow[t]{2}{*}{ Gender } & Male & Female \\
\hline & $303(70.0 \%)$ & $130(30.0 \%)$ \\
\hline \multirow[t]{2}{*}{ Race } & Caucasian & All others \\
\hline & $155(35.8 \%)$ & $278(64.2 \%)$ \\
\hline \multirow[t]{2}{*}{ County } & Urban & Rural \\
\hline & $343(79.2 \%)$ & $90(20.8 \%)$ \\
\hline \multicolumn{3}{|l|}{ Education } \\
\hline Severely behaviorally handicapped & $29(6.7 \%)$ & $404(93.3 \%)$ \\
\hline Developmentally handicapped & $5(1.2 \%)$ & $428(98.8 \%)$ \\
\hline Severely emotionally disturbed & $30(6.9 \%)$ & $403(93.1 \%)$ \\
\hline \multicolumn{3}{|l|}{ Mental health } \\
\hline Attention-deficit/hyperactivity disorder & $103(23.8 \%)$ & $330(76.2 \%)$ \\
\hline Conduct disorder & $40(9.2 \%)$ & $393(90.8 \%)$ \\
\hline Oppositional defiant disorder & $33(7.6 \%)$ & $400(92.4 \%)$ \\
\hline Bipolar disorder & $34(7.9 \%)$ & $399(92.1 \%)$ \\
\hline Depression & $52(12.0 \%)$ & $381(88.0 \%)$ \\
\hline Adjustment disorder & $10(2.3 \%)$ & $423(97.7 \%)$ \\
\hline Posttraumatic stress disorder & $10(2.3 \%)$ & $423(97.7 \%)$ \\
\hline Anxiety disorder & $11(2.5 \%)$ & $422(97.5 \%)$ \\
\hline Substance dependent & $64(14.8 \%)$ & $369(85.2 \%)$ \\
\hline Suicide attempt & $53(12.2 \%)$ & $380(87.8 \%)$ \\
\hline \multicolumn{3}{|l|}{ Child welfare } \\
\hline Maltreatment & $263(60.7 \%)$ & $170(39.3 \%)$ \\
\hline \multicolumn{3}{|l|}{ Juvenile court } \\
\hline No. of delinquency adjudications & \multicolumn{2}{|c|}{$M=1.3(S D=0.6)$} \\
\hline Age at first delinquency adjudication & \multicolumn{2}{|c|}{$M=14.6(S D=1.6)$} \\
\hline No. of court offenses & \multicolumn{2}{|c|}{$M=4.4(S D=3.8)$} \\
\hline Felony & $237(54.9 \%)$ & $195(45.1 \%)$ \\
\hline Misdemeanor & $358(82.7 \%)$ & $75(17.3 \%)$ \\
\hline Property crime & $238(55.0 \%)$ & $195(45.0 \%)$ \\
\hline Personal crime $^{\mathrm{a}}$ & $261(60.4 \%)$ & $171(39.6 \%)$ \\
\hline Drug crime ${ }^{\mathrm{b}}$ & $85(64.9 \%)$ & $346(80.3 \%)$ \\
\hline Violation of a court order & $149(34.5 \%)$ & $283(65.5 \%)$ \\
\hline
\end{tabular}

${ }^{\mathrm{a}} 1$ missing case. ${ }^{\mathrm{b}} 2$ missing cases.

Hosmer-Lemeshow goodness-of-fit checks $(p=.482$ and $p=.477$, respectively, for the Caucasian and minority youth models) and had reasonable model performance statistics.

The final model for Caucasian youth included severely behaviorally handicapped special education disability, number of court-related offenses, and violation of a court order. During validation modeling the same variables were identified, and the estimates are presented in Table 3. The overall model was significant at predicting detention placement recidivism, $\chi^{2}(2)=61.888$, 
TABLE 2 Univariate Analyses With Race as the Dependent Variable $(n=433)$

\begin{tabular}{|c|c|c|c|}
\hline Variable & Minority & Caucasian & $p$ \\
\hline \multicolumn{4}{|l|}{ Predictor } \\
\hline Recidivated to placement & $52(18.7 \%)$ & $19(12.3 \%)$ & 0.082 \\
\hline \multicolumn{4}{|l|}{ Control } \\
\hline Age $(\text { years) })^{a}$ & $15.2 \pm 1.6$ & $15.3 \pm 1.6$ & 0.878 \\
\hline Male & $207(74.5 \%)$ & $96(61.9 \%)$ & 0.006 \\
\hline Urban & $259(93.2 \%)$ & $84(54.2 \%)$ & $<.001$ \\
\hline \multicolumn{4}{|l|}{ Education } \\
\hline Severely behaviorally handicapped & $15(5.4 \%)$ & $14(9.0 \%)$ & 0.147 \\
\hline Developmentally handicapped & $3(1.1 \%)$ & $2(1.3 \%)$ & 1.000 \\
\hline Severely emotionally disturbed & $25(9.0 \%)$ & $5(3.2 \%)$ & 0.024 \\
\hline \multicolumn{4}{|l|}{ Mental health } \\
\hline Attention-deficit/hyperactivity disorder & $61(21.9 \%)$ & $42(27.1 \%)$ & 0.227 \\
\hline Conduct disorder & $29(10.4 \%)$ & $11(7.1 \%)$ & 0.251 \\
\hline Oppositional defiant disorder & $15(5.4 \%)$ & $18(11.6 \%)$ & 0.019 \\
\hline Bipolar disorder & $16(5.8 \%)$ & $18(11.6 \%)$ & 0.030 \\
\hline Depression & $40(14.4 \%)$ & $12(7.7 \%)$ & 0.041 \\
\hline Adjustment disorder & $8(2.9 \%)$ & $2(1.3 \%)$ & 0.292 \\
\hline Posttraumatic stress disorder & $7(2.5 \%)$ & $3(1.9 \%)$ & 0.699 \\
\hline Anxiety disorder & $9(3.2 \%)$ & $2(1.3 \%)$ & 0.217 \\
\hline Substance dependent & $38(13.7 \%)$ & $26(16.8 \%)$ & 0.383 \\
\hline Suicide attempt & $38(13.7 \%)$ & $15(9.7 \%)$ & 0.224 \\
\hline \multicolumn{4}{|l|}{ Child welfare } \\
\hline Maltreatment & $125(45.0 \%)$ & $45(29.0 \%)$ & 0.001 \\
\hline \multicolumn{4}{|l|}{ Juvenile court } \\
\hline No. of delinquency adjudications ${ }^{\mathrm{a}}$ & $1.3 \pm 0.6$ & $1.3 \pm 0.5$ & 0.547 \\
\hline Age at first delinquency adjudication (years) ${ }^{\mathrm{a}}$ & $14.6 \pm 1.6$ & $14.6 \pm 1.5$ & 0.987 \\
\hline No. of court offenses ${ }^{a}$ & $4.2 \pm 3.8$ & $4.7 \pm 3.7$ & 0.183 \\
\hline Felony & $165(59.6 \%)$ & $72(46.5 \%)$ & 0.009 \\
\hline Misdemeanor & $222(79.9 \%)$ & $136(87.7 \%)$ & 0.038 \\
\hline Property crime & $144(51.8 \%)$ & $94(60.7 \%)$ & 0.076 \\
\hline Personal crime & $173(62.2 \%)$ & $88(57.1 \%)$ & 0.300 \\
\hline Drug crime & $51(18.4 \%)$ & $34(22.1 \%)$ & 0.359 \\
\hline Violation of a court order & $94(33.9 \%)$ & $55(35.5 \%)$ & 0.745 \\
\hline
\end{tabular}

${ }^{\mathrm{a}}$ Mean $\pm S D$.

$p<.001$, sample size $=433$, and correctly classified $93.5 \%$ of the cases. The Nagelkerke $R^{2}$ was .626 .

The final model for minority youth included violation of court order, number of court offenses, age of the youth, child welfare, ADHD, prior

TABLE 3 Multivariable Logistic Regression Predicting Detention Placement Upon Recidivism for Caucasian Youth

\begin{tabular}{lccrr}
\hline Independent Variable & $B$ & $S E$ & Wald & Odds Ratio \\
\hline Violation of a court order & $1.745^{*}$ & 0.805 & 4.702 & 5.725 \\
No. of court offenses & $0.459^{* *}$ & 0.117 & 15.263 & 1.582 \\
Severely behaviorally handicapped & $2.604^{*}$ & 1.042 & 6.242 & 13.523 \\
Constant & -6.314 & 1.187 & 28.297 & 0.002 \\
\hline
\end{tabular}

${ }^{*} p<.05,{ }^{* *} p<.001$. 
TABLE 4 Multivariable Logistic Regression Predicting Detention Placement Upon Recidivism for Minority Youth

\begin{tabular}{lccrc}
\hline Independent Variable & $B$ & $S E$ & Wald & Odds Ratio \\
\hline Violation of a court order & $-1.639^{* *}$ & 0.522 & 8.851 & 0.194 \\
No. of court offenses & $0.365^{* * *}$ & 0.075 & 23.951 & 1.441 \\
Age & $0.356^{*}$ & 0.163 & 4.806 & 1.428 \\
Child welfare & $1.216^{* *}$ & 0.455 & 7.124 & 3.372 \\
Attention-deficit/hyperactivity disorder & $-1.168^{*}$ & 0.572 & 4.174 & 0.311 \\
Suicide attempt & $1.595^{* *}$ & 0.556 & 8.226 & 4.928 \\
Felony & $1.603^{* *}$ & 0.605 & 7.006 & 4.966 \\
Misdemeanor & $-1.141^{*}$ & 0.537 & 4.516 & 0.319 \\
Conduct disorder & $2.645^{* * *}$ & 0.638 & 17.185 & 14.084 \\
Constant & $-9.710^{* *}$ & 2.793 & 12.082 & 0.000 \\
\hline
\end{tabular}

${ }^{*} p<.05,{ }^{* *} p<.01,{ }^{* * *} p<.001$.

suicide attempt, felony and misdemeanor offenses, and conduct disorder. During validation modeling the same variables were identified, and the estimates are presented in Table 4 . The overall model was significant at predicting recidivism, $\chi^{2}(9)=110.036, p<.001$, sample size $=433$, and correctly classified $88.0 \%$ of the cases. The Nagelkerke $R^{2}$ was .530 .

\section{FINDINGS}

Results from the analysis suggest that extralegal variables (demographic, educational, child welfare, mental health variables) and legal, juvenile court-related variables predict racial differences in detention placement upon recidivism. Specifically, only three variables significantly predicted detention placement for Caucasian youth (see Table 3). Having a previously documented special education disability (severely behaviorally handicapped) made Caucasian youth more than 13 times more likely to receive detention placement upon recidivism. The other two variables that were significant predictors for Caucasian youth were court-related variables: For each additional court offense detention placement upon recidivism was 1.5 times more likely, and violation of a court order made detention placement upon recidivism almost 6 times more likely. No additional demographic, child abuse or neglect, or mental health variables significantly predicted detention placement upon recidivism for Caucasian youth.

Analysis of data on minority youth revealed a distinctly different pattern (see Table 4). Six variables increased this group's likelihood of detention placement upon recidivism. In terms of demographic characteristics, for every 1-year increase in age minority youth were almost 1.5 times more likely to be detained for recidivism. Similarly, prior child welfare involvement (abuse or neglect victimization) made them 3 times more likely to receive detention 
placement upon recidivism. Regarding mental health-related variables, minority youth with a previous reported suicide attempt were nearly 5 times more likely, and those with a previous diagnosis of conduct disorder nearly 14 times more likely, to receive detention placement upon recidivism. Like Caucasian youth, minority youth had a moderate increase in their likelihood (1.4 times more likely) to receive detention placement upon recidivism as the total number of court offenses increased.

Three variables decreased the likelihood that minority youth would receive detention placement upon recidivism. Minority youth with a diagnosis of ADHD were almost 3 times less likely to receive detention placement upon recidivism. Two court-related variables also decreased the likelihood of receiving detention placement upon recidivism. As one might expect, because of the lower level of offense, committing a misdemeanor made detention placement just more than 3 times less likely; but an unexpected finding was that having violated a court order made detention placement just more than 5 times less likely for minority youth.

\section{DISCUSSION}

This study identifying predictors of detention placement upon recidivism is rare in the literature. In addition, past studies have more frequently measured recidivism as youth reoffending or being rearrested, or they have simply calculated the return rate to placement facilities. In contrast, we measured recidivism as a return placement to a juvenile detention center yet furthered the investigation by searching for predictive factors for this placement after recidivism. These predictive factors included known delinquency risk factors, and we hypothesized that these school, mental health, child welfare, and court involvement factors were important. We focused on the detention placement measurement because of the harmful outcomes linked to detention but further hypothesized whether there were differing predictive factors based on the youth's race. Differences based on race were found, these findings are either perplexing or illuminating, depending on one's viewpoint.

Overall two variables significantly predicted detention placement upon recidivism for both Caucasian and minority youth. As was expected, both variables pertained to legal characteristics of youthful offenders. First, each additional increase in the total number of court offenses made detention placement 1.7 times more likely for Caucasians and 1.4 times more likely for minorities. Second, having a court order violation record made Caucasian youth more than 8 times more likely and minority youth more than 5 times less likely to receive detention placement upon recidivism.

The other significant variables that predicted detention placement upon recidivism varied by race. A special education disability was predictive for Caucasian youth but not for minority youth. Other disability variables were 
significant only for minority youth-with conduct disorder being predictive of detention placement upon recidivism, but not ADHD. It may be that the reason ADHD predicts detention placement but makes this outcome less likely is that youth with ADHD have already come to the attention of the mental health or school systems prior to their court involvement. Thus, it may be that effective interventions have had an impact on these youth, making it less likely for such youth to be placed in detention.

No other specific mental health (or substance abuse) diagnoses were predictive of detention placement for either Caucasian or minority youth; however, a related mental health difficulty was found. A past suicide attempt was a predictor of detention placement for minority youth, presenting an intervention opportunity for juvenile court personnel. Identifying youth who have a past suicide attempt may allow juvenile court personnel to predict both future recidivism and detention placement of the youth, and it also may assist in addressing the underlying mental health concerns that quite possibly affect both suicidal tendency and delinquent behaviors.

The remaining significant difference by race was a youth's past abuse or neglect victimization, which was a predictor of detention placement upon recidivism for minority but not Caucasian youth. If further investigations confirm this pattern it may be possible for juvenile court personnel to more easily identify which youth under their supervision are most at risk for future detention placements. Generally speaking, research findings such as these can help juvenile court personnel know which subgroups of their large youthful offender population are more at risk for the outcomes the courts may be trying to minimize, including reoffending and recidivism. This sort of knowledge can help drive juvenile court practice through making personnel better able to identify, and then intervene earlier with, those youthful offenders who are most at risk for future recidivism and thus an increased likelihood of receiving detention dispositions.

Differential treatment theory helps frame and interpret the findings of this study. This theory postulates that characteristics of youth, family, neighborhood, school, and so on that may be strongly related to race may in turn have a significant impact on the treatment by juvenile court personnel, furthering or causing disproportionate minority confinement. Although not dispositive, the significant predictive differences found here for minority youth were individual, family, and school related. The fact that a youth has a history of abuse or neglect, suicide attempts, and/or severe behavioral or mental health problems may be impacting the decisions of juvenile court personnel at many levels. It may be possible that these related problems are viewed within a rehabilitative framework and that the juvenile courts may be utilizing detention center placements as safe places (treatment referrals) for youth (e.g., instead of returning them to an abusive home). Or it may be that these trauma and mental health difficulties are unknown to the juvenile court personnel who are making these decisions, or their negative impact 
on youth development and decision making is underappreciated (Grisso \& Schwartz, 2000; Sedlak \& McPherson, 2010). Either way, further investigations are necessary to more fully determine the impact these individual and family difficulties may have on juvenile courts' decision to use detention and placement as a dispositional outcome. In addition, why the violation of a court order differs significantly by race should be pursued, for it may be that minority youth are being treated differently by judges because of ongoing disproportionate minority confinement concerns.

\section{Limitations}

This research has some important limitations that must be noted. First, although a random sampling method was used to select cases for inclusion in this study, the sampling frame itself was limited to only two midwestern counties in the United States. This limits the generalizability of the findings. Second, secondary analysis of existing case records was used to extract data, and the extent to which there were errors in the original data is unknown. Another limitation is the possibility that some youth with prior mental health problems were never formally diagnosed. In addition, even if youth were diagnosed, there is a possibility that not all of them were correctly classified. The final and most significant limitation may be that the data collected were from one juvenile justice system decision point, at probation and supervision. Although the records used in this study did provide information concerning court supervision, no information on earlier youth contact points (arrest, diversion) was available. Thus, it was not possible to test the structuralprocessual theory of disproportionate minority confinement. In order to account for these limitations, replication of this study with a larger sampling frame and across different juvenile justice system decision-making points is in order. In addition, further explication as to why a court order violation predicted detention placement for Caucasian youth but not for minority youth is worthwhile because the factors that affect court order violations (e.g., previous violations, probation compliance, severity of offense, judicial personnel involved) are undoubtedly influential. These variables were not fully available for this investigation.

\section{Conclusion}

Minimizing the placement and detention of youthful offenders is important juvenile justice policy because of the negative effects of these outcomes. Although there may be a limited number of circumstances in which detainment is the most appropriate solution-for community or youth safety-most situations do not call for this placement. In the United States not only is detention utilized fairly frequently, but this placement outcome has been 
disproportionately impacting minority youth for more than two decades. Much effort has been and will continue to be focused on identifying the correlates and causes of this juvenile justice system conundrum, but with limited success. The findings here provide a small prism of understanding of racial differences that may predict the use of detention placement in two juvenile court jurisdictions in the United States. As these investigations continue it is hoped that a more complete understanding can be attained, allowing permanent juvenile justice system changes to be made to alleviate disproportionate minority confinement.

\section{REFERENCES}

American Psychiatric Association. (2000). Diagnostic and statistical manual of mental disorders (4th ed., text rev.). Washington, DC: Author.

Bishop, D. M. (2006). The role of race and ethnicity in juvenile justice processing. In D. F. Hawkins \& K. Kempf-Leonard (Eds.), Our children, their children: Confronting racial and ethnic differences in American juvenile justice (pp. 23-82). Chicago, IL: The University of Chicago Press.

Bishop, D., \& Frazier, C. E. (1992). Gender bias in juvenile justice processing: Implications for the JJDP Act. Journal of Criminal Law and Criminology, 82, 1162-1866.

Bortner, M. A., Sunderland, M. A., \& Winn, R. (1985). Race and impact of juvenile deinstitutionalization. Crime and Delinquency, 31(1), 35-46.

Breda, C. S. (2003). Offender ethnicity and mental health service referrals from juvenile courts. Criminal Justice and Behavior, 30, 644-667.

Bridges, G. S., Crutchfield, R. D., \& Simpson, E. (1987). Crime, social structure and criminal punishment: White and nonwhite rates of imprisonment. Social Problems, 34, 345-361.

Bridges, G. S., \& Steen, S. (1998). Racial disparities in official assessments of juvenile offenders: Attibutional stereotypes as mediating mechanisms. American Sociological Review, 63, 554-570.

Center for Juvenile Justice Reform. (2010). The crossover youth practice model. Washington, DC: Georgetown University.

Chassin, L. (2008). Juvenile justice and substance abuse. The Future of Children, 18(2), 165-184.

Cohen, L. E., \& Kluegel, J. R. (1978). Determinants of juvenile court dispositions: Ascriptive and achieved factors in two metropolitan courts. American Sociological Review, 43, 162-176.

Engen, R. L., Steen, S., \& Bridges, G. S. (2002). Racial disparities in the punishment of youth: A theoretical and empirical review of the literature. Social Problems, 49(2), 194-220.

Farmer, T. W., Price, L. N., O'Neal, K. K., Leung, M. C., Goforth, J. B., Cairns, B. D., \& Reese, L. E. (2004). Exploring risk in early African American youth. American Journal of Community Psychology, 33(1/2), 41-60.

Ford, J. D., Chapman, J. F., Hawke, J., \& Albert, D. (2007). Trauma among youth in the juvenile justice system: Critical issues and new directions. New York, NY: National Center for Mental Health and Juvenile Justice. 
Garland, A., Hough, R. L., McCabe, K. M., Yeh, M., Wood, P. A., \& Aarons, G. A. (2001). Prevalence of psychiatric disorders in youths across five sectors of care. Journal of the American Academy of Child and Adolescent Psychiatry, 40, 409-418.

Gavazzi, S. M., Yarcheck, C. M., \& Lim, J. Y. (2005). Ethnicity, gender, and global risk indicators in the lives of status offenders coming to the attention of the juvenile court. International Journal of Offender Therapy and Comparative Criminology, 49, 696-710.

Glisson, C. (1996). Judicial and service decisions for children entering state custody: The limited role of mental health. Social Service Review, 70, 257-281.

Green, A. E., Gesten, E. L., Greenwald, M. A., \& Salcedo, O. (2008). Predicting delinquency in adolescence and young adulthood. Youth Violence and Juvenile Justice, 6, 323-342.

Grisso, T. (2008). Adolescent offenders with mental disorders. The Future of Children, 18(2), 143-164.

Grisso, T., \& Schwartz, R. G. (2000). Youth on trial: A developmental perspective on juvenile justice. Chicago, IL: University of Chicago Press.

Gutman, L. M., Sameroff, A. J., \& Cole, R. (2003). Academic growth curve trajectories from 1st grade to 12th grade: Effects of multiple social risk factors and preschool child factors. Developmental Psychology, 39, 777-790.

Hawkins, D. F. (1987). Beyond anomalies: Rethinking the conflict perspective on race and criminal punishment. Social Forces, 65, 719-745.

Hill, G. D., Harris, A. R., \& Miller, J. (1985). The etiology of bias: Social heuristics and rational decision making in deviance processing. Journal of Research in Crime and Delinquency, 22, 135-162.

Holman, B., \& Ziedenberg, J. (2006). The dangers of detention: The impact of incarcerating youth in detention and other secure congregate facilities. Baltimore, MD: Annie E. Casey Foundation.

Horwitz, A., \& Wasserman, H. (1980). Some misleading conceptions in sentencing research. Criminology, 18, 411-424.

Johnson, J. B., \& Secret, P. E. (1990). Race and juvenile court decision making revisited. Criminal Justice Policy Review, 4, 159-187.

Kempf-Leonard, K. (2007). Minority youths and juvenile justice: Disproportionate minority contact after nearly 20 years of reform efforts. Youth Violence and Juvenile Justice, 5, 71-87.

Knoll, C., \& Sickmund, M. (2010). Delinquency cases in juvenile court, 2007. Washington, DC: Office of Juvenile Justice and Delinquency Prevention.

Krezmien, M. P., Mulcahy, C. A., \& Leone, P. E. (2008). Detained and committed youth: Examining differences in achievement, mental health needs, and special education status. Education and Treatment of Children, 31, 445-464.

Leiber, M. J., \& Fox, K. C. (2005). Race and the impact of detention on juvenile justice decision making. Crime \& Delinquency, 51, 470-497.

Mallett, C. (2009). Disparate juvenile court outcomes for disabled delinquent youth: A social work call to action. Child \& Adolescent Social Work Journal, 26(3), 197-208.

Mallett, C., \& Julian, L. (2008). Alternatives for youth's advocacy program: Effectively reducing minority youth's detention and incarceration placements in Cleveland, Ohio. Juvenile and Family Court Journal, 59(3), 1-17. 
Mallett, C., \& Stoddard-Dare, P. (2010). Predicting secure detention placement for African American juvenile offenders: Addressing the disproportionate minority confinement problem. Journal of Ethnicity in Criminal Justice, 8(2), 91-103.

Martin, T. W., \& Grubb, H. J. (1990). Race bias in diagnosis and treatment of juvenile offenders: Findings and suggestions. Journal of Contemporary Psychotherapy, 20, 259-272.

Mauer, M., \& King, R. S. (2007). Uneven justice: State rates of incarceration by race and ethnicity. Washington, DC: The Sentencing Project.

Meade, A. C. (1973). Seriousness of delinquency: The adjudicative decision and recidivism-A longitudinal configuration analysis. Journal of Criminal Law and Criminology, 64, 478-485.

Mears, D., \& Aron, L. (2003). Addressing the needs of youth with disabilities in the juvenile justice system: The current state of knowledge. Washington, DC: The Urban Institute.

National Center for Juvenile Justice. (2006). State juvenile justice profiles. Pittsburgh, PA: Author.

National Council on Crime and Delinquency. (2007). And justice for some: Differential treatment of youth of color in the justice system. Washington, DC: Nation Council on Crime and Delinquency.

Piquero, A. R. (2008). Disproportionate minority contact. The Future of Children, 18(2), 59-79.

Pope, C. E., \& Feyerherm, W. H. (1990). Minority status and juvenile justice processing: An assessment of the research literature (Part I). Criminal Justice Abstracts, 22, 327-335.

Puzzanchera, C., Adams, B., \& Snyder, H. (2008). An interpretation of the national $D M C$ relative rate indices for juvenile justice system processing in 2005. Washington, DC: Office of Juvenile Justice and Delinquency Prevention.

Rodriquez, N. (2010). The cumulative effect of race and ethnicity in juvenile court outcomes and why preadjudication detention matters. Journal of Research in Crime and Delinquency, 47, 391-413.

Rogers, K. M., Powell, E., \& Strock, M. (1998). The characteristics of youth referred for mental health evaluation in the juvenile justice system. In J. Willis, C. Liberton, K. Kutash, \& R. Friedman (Eds.), The 10th annual research conference proceedings: A system of care for children's mental health: Expanding the research base (pp. 329-334). Tampa: University of South Florida.

Royse, D., Thyer, B., Padgett, D., \& Logan, T. (2006). Program evaluation: An introduction. Belmont, CA: Thompson Brooks/Cole.

Sampson, R. J., \& Laub, J. H. (1993). Structural variations in juvenile court processing: Inequality, the underclass, and social control. Law and Society Review, 27(2), 285-311.

Scott, M. A., Snowden, L., \& Libby, A. M. (2002). From mental health to juvenile justice: What factors predict this transition? Journal of Child and Family Studies, 11(3), 299-311.

Sedlak, A. J., \& Bruce, C. (2010). Youth's characteristics and backgrounds: Findings from the survey of youth in residential placement. Washington, DC: Office of Juvenile Justice and Delinquency Prevention.

Sedlak, A. J., \& McPherson, K. (2010). Survey of youth in residential placement: Youth's needs and services. Washington, DC: Westat. 
Sickmund, M. (2008). Census of juveniles in residential placement databook. Washington, DC: Office of Juvenile Justice and Delinquency Prevention.

Teplin, L., Abram, K., McClelland, G., Mericle, A., Dulcan, M., \& Washburn, D. (2006). Psychiatric disorders of youth in detention. Washington, DC: Office of Juvenile Justice and Delinquency Prevention.

Tuell, J. (2002). Child maltreatment and juvenile delinquency: Raising the level of awareness. Washington, DC: Child Welfare League of America, National Center for Program Standards and Development, Juvenile Justice Division.

U.S. Department of Justice. (2010). Performance measures. Washington, DC: Office of Juvenile Justice and Delinquency Prevention.

Wu, B. (1997). The effect of race and juvenile justice processing. Juvenile \& Family Court Judges, 48, 43-51. 